\title{
Transition from discontinuous to continuous paste filling at Cannington Mine
}

\author{
J Li BHP Billiton, Australia \\ JV Ferreira BHP Billiton, Australia \\ T Le Lievre BHP Billiton, Australia
}

\begin{abstract}
Cannington Mine is an underground multi-metal mine that uses the sublevel open stoping mining method. The majority (>95\%) of the void created by this mining method is filled with paste, a mixture of process tailings, cement and water. For each void to be filled all level openings are sealed with a fibrecrete fill wall. The cemented paste fill allows for a continuous retreating sequence between primary and secondary (or tertiary) stopes. Backfilling is an integral part of the mining cycle; consequently a reliable and productive paste fill system is required with integration between both surface infrastructure and the underground paste filling strategy.
\end{abstract}

To mitigate the risk of fill wall failure due to the pressure imposed on each fill wall by uncured paste fill a discontinuous filling strategy (or stop and cure process) was used at Cannington Mine. When the paste fill level in a stope was passing a level opening with a fill wall present, paste filling was stopped or slowed to allow the paste fill to cure. This discontinuous paste filling strategy caused 15-20\% of paste fill downtime, each stop and cure usually involved changing to fill an alternate stope and required fill line flushing to clear paste from reticulation network after completion of and before starting up each fill run, and fill line changing.

A project was established in mid 2011 to investigate the effects of continuously paste filling behind a fill wall. The project involved numerical modelling of the strength of fibrecrete fill walls with various dimensions (width, height and thickness), correlated data gathered from in situ fill wall pressure monitoring, using pressure cells with varying vertical rate of rise, and different paste fill cement contents. The data analysis led to operational procedure updates allowing continuous paste filling and the establishment of a wall thickness design tool.

Project outcomes saw continuous filling behind both arched and flat fibrecrete fill walls, which resulted in a $15 \%$ reduction in paste fill down time; it allowed a reduction in fibrecrete fill wall thickness, which reduced fibrecrete consumption by $30 \%$ on average; and led to a reduction in paste fill line changes, which increased paste crew productivity, and decreased the frequency of cold joints caused by flushing in paste fill masses. A continuous paste fill strategy was successfully implemented and has been applied without incident since project completion in early 2012.

\section{Introduction}

This paper outlines the methodology, results and conclusions drawn from a project initiated at Cannington Mine to investigate the potential to transition from a discontinuous to a continuous paste filling strategy.

Discontinuous paste filling strategy (or stop and cure) was used to mitigate the risk of fill wall failure due to the pressure imposed on each fill wall by uncured paste fill. When the paste fill in a stope was passing a fill wall at an access level opening, paste filling was stopped or slowed to allow the paste fill to cure. Prior to the initiation of the project, the strength of fill walls and the actual pressure applied by the paste fill was unknown. With the available information at the time, discontinuous filling was an adequate control to minimise the likelihood of fill wall failure which presents a potential risk to the underground personnel, infrastructure, equipment, and production. 
The aim was to indicate that continuous filling past a fill wall could be conducted safely, and pose no additional risk to the underground environment. This was substantiated by determining the strength of the fill walls used at Cannington mine, measuring the actual pressure applied to the fill walls by paste fill, and establishing wall thickness design template for routine operational application.

\section{Background and historical information}

Continuous filling is a relatively new paste filling strategy, used at a number of underground mines worldwide (Yumlu \& Guresci 2007; Thompson et al. 2009; Bawden 2010; Hughes et al. 2010). Studies on continuous filling strategy and wall stability have mainly focused on monitoring of the pressure applied on the fill wall, and in-stope vertical and horizontal stresses during paste filling (Yumlu \& Guresci 2007; Grabinsky \& Bawden 2007; Thompson et al. 2009; Bawden 2010; Hughes et al. 2010). Helinski et al. (2007) used their specifically designed software Minefill-2D to calculate the fill wall stresses from measured pore pressures.

The paste plant at Cannington Mine became operational in December 1997 (Bloss \& Revell 2000). The paste plant can produce paste fill at a maximum rate of $420 \mathrm{t} / \mathrm{hr}\left(190 \mathrm{~m}^{3} / \mathrm{hr}\right)$, and the stope or void dimensions determine the vertical rate of rise of paste fill. Paste fill at Cannington is a mixture of dewatered tailings and cement, the cement content varies between $2.7-6 \%$ by weight, depending on future adjacent mining activities.

Historically at Cannington Mine, aquacrete bag walls had been constructed as fill walls before Jumbo walls were introduced in 2000. Jumbo walls are installed using a Jumbo drilling machine to pin mesh across a drive, the mesh is then covered with hessian and sprayed with fibrecrete. Kit walls, both arched and flat, were introduced at Cannington Mine in 2009, and are used in the majority of cases. They are made of a steel frame, covered with mesh and hessian and then sprayed with fibrecrete to the required thickness. Jumbo walls are still installed in drives $>9 \mathrm{~m}$ wide and/or $>7 \mathrm{~m}$ high, which are greater than the dimensions of the Kit walls. Figure 1 shows sketches of a Jumbo wall and arched Kit wall, while Figure 2 presents an arched Kit wall before fibrecreting and framework of a flat Kit wall erected at $5 \mathrm{~m}$ from an open stope brow. The depth indicators are to ensure that the designed wall thickness is achieved and the wall capacity is maintained.

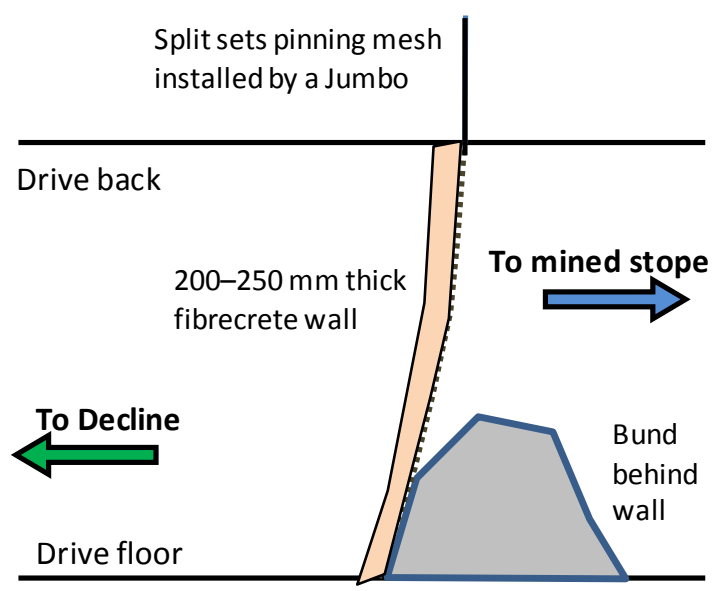

(a)

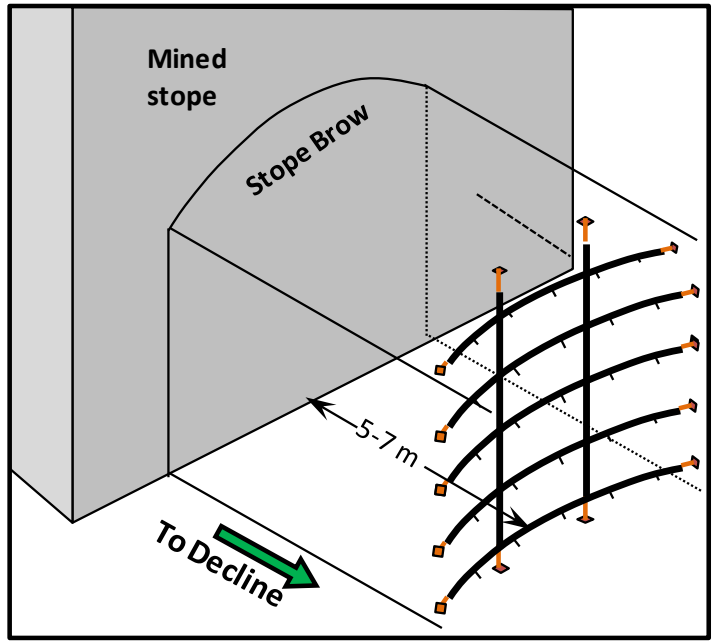

(b)

Figure 1 Sketches of Jumbo wall (a); and arched Kit wall (b) 


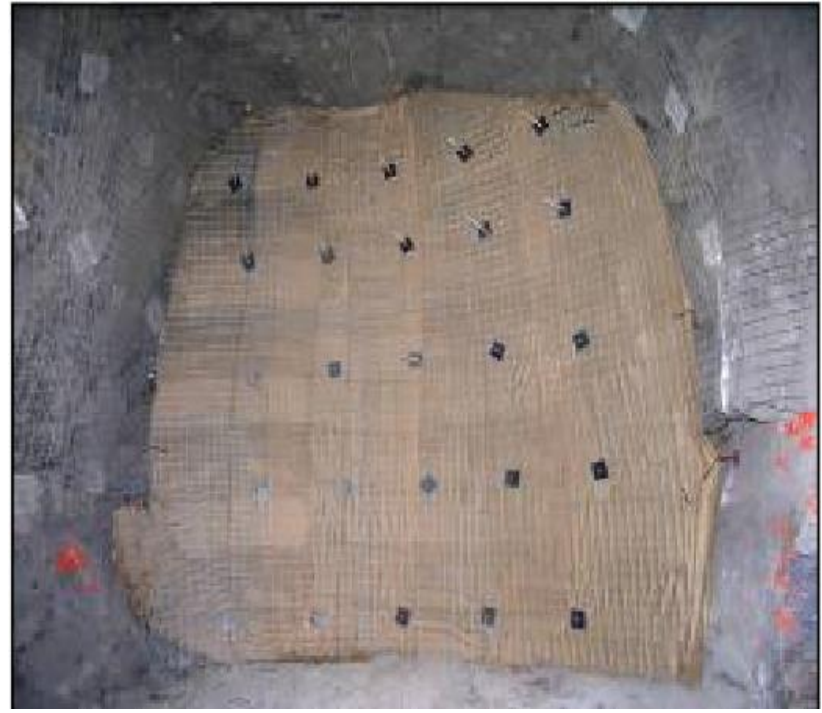

(a)

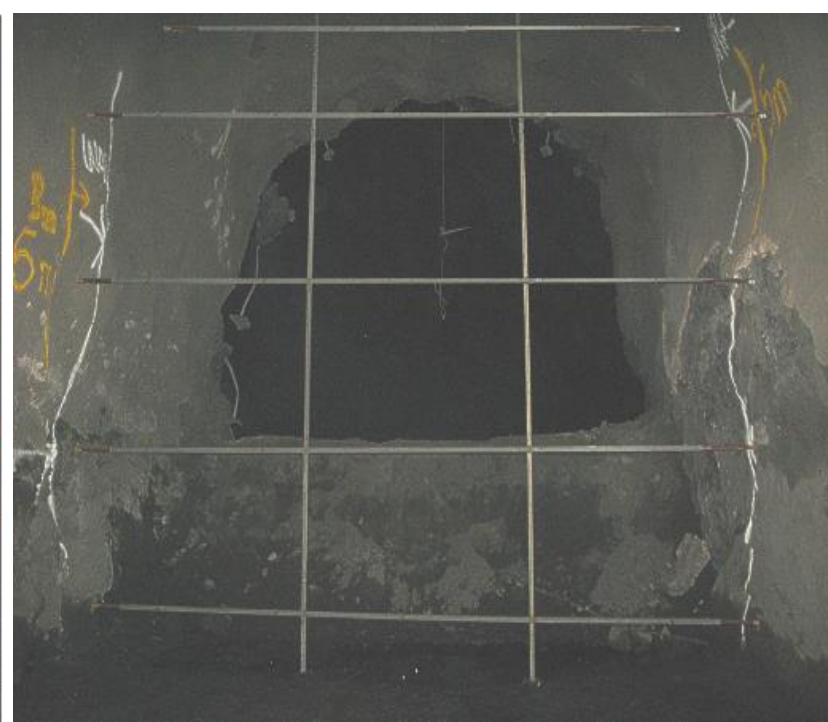

(b)

Figure 2 (a) an arched Kit wall with hessian and depth indicator installed; and (b) installed flat Kit wall framework at $5 \mathrm{~m}$ to the stope brow

Prior to completion of this project, all Kit walls and Jumbo walls were sprayed with fibrecrete to $400 \mathrm{~mm}$ thick regardless of the vertical rate of rise, cement content in the paste fill and the width/height of the walls. The continuous fill strategy was only allowed where a design vertical rate of rise is equal to or less than $0.3 \mathrm{~m} / \mathrm{hr}$.

This discontinuous paste filling strategy caused $15-20 \%$ of paste fill downtime, as each stop and cure usually involved filling an alternate stope and also required fill line flushing to clear paste from the reticulation network after completion of and before starting up each fill run. In general, the minimum paste fill curing period was 12 hours.

\section{$3 \quad$ Arched and flat Kit wall capacities}

Knowing the loading capacity of paste fill walls with different dimensions is an important part for the sustainable and safe application of the continuous filling strategy in daily paste fill operations. The FLAC3D modelling was previously used for fill wall capacity investigation in other operations (Sainsbury \& Revell 2007).

Investigation into the capacity of the fibrecrete fill walls was carried out using the FLAC3D numerical modelling software in 2009 (Revell et al. 2009). This extensive numerical modelling work included both arched and flat Kit walls with thicknesses ranging from 0.2-0.6 m, width ranging from 5-7 $\mathrm{m} \mathrm{(9} \mathrm{m} \mathrm{for} \mathrm{flat}$ walls) and height ranging from 5-7 m. Figure 3 presents the ultimate capacities for a $5 \mathrm{~m}$ wide by $5 \mathrm{~m}$ high wall (a) and a $5 \mathrm{~m}$ wide by $6 \mathrm{~m}$ high wall (b). The model was run with fibrecrete cured for 48 hours, when the fibrecrete had an unconfined compressive strength of $18.6 \mathrm{MPa}$, a tensile strength of $2.3 \mathrm{MPa}$, a Young's modulus of $14.6 \mathrm{GPa}$, and a friction angle of $37^{\circ}$. Field early strength testing conducted in 2006 at Cannington Mine (Bernard 2006; Li et al. 2011) confirmed the compressive strength used in modelling was realistic. The modelling results indicated that flat walls have much lower capacities than arched fibrecrete walls for a given thickness. 

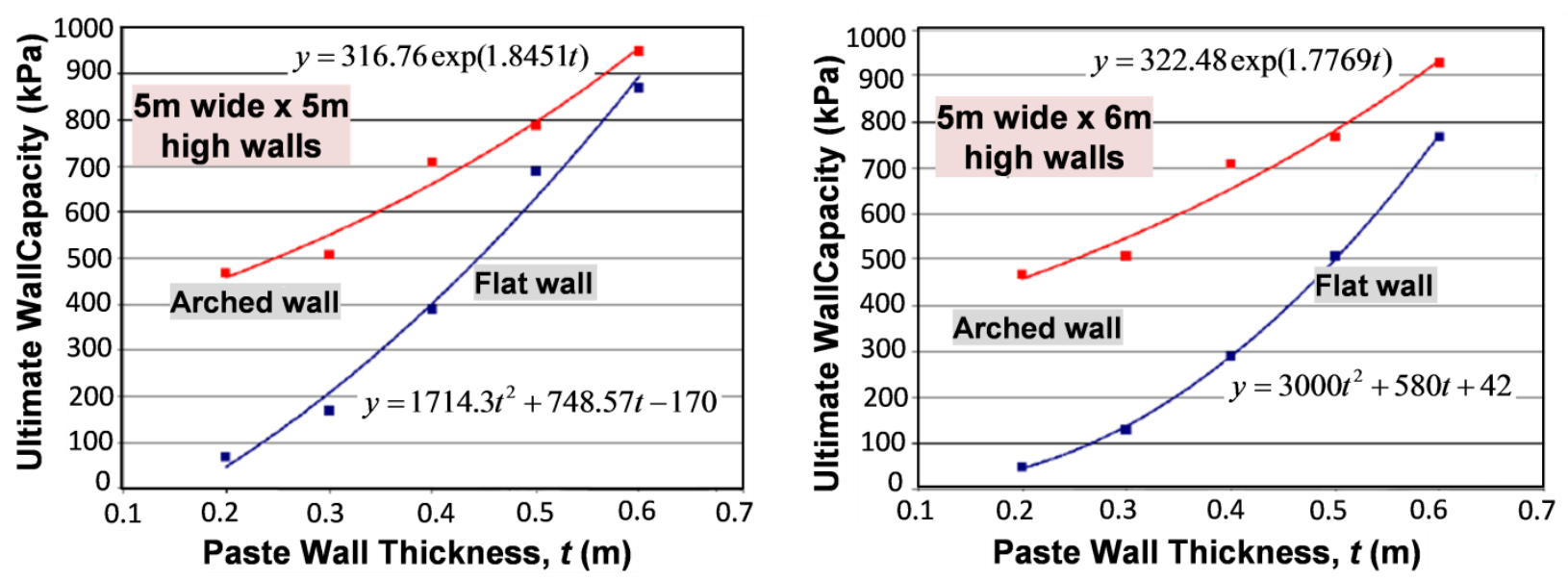

Figure 3 Numerical modelling provided ultimate capacity of $5 \mathrm{~m}$ wide walls having $0.2-$ $0.6 \mathrm{~m}$ thick fibrecrete after 48 hours curing (re-plotted from Revell et al. 2009)

The fill wall model assumes that an evenly distributed pressure is applied across the entire surface area of the wall, and the contact between the fill wall and surrounding rock is simplified (Figure 4(a)). In reality, the pressure is gradually decreased from the drive floor to drive backs. At Cannington Mine extra fibrecrete is sprayed to wall contacts with drive backs, walls and floor, an additional $0.5 \mathrm{~m}$, to assist with the quality of the drive to wall contact (Figure 4(b)). Therefore, the Kit wall capacities established from the FLAC3D numerical modelling are conservative and can be accepted with confidence.

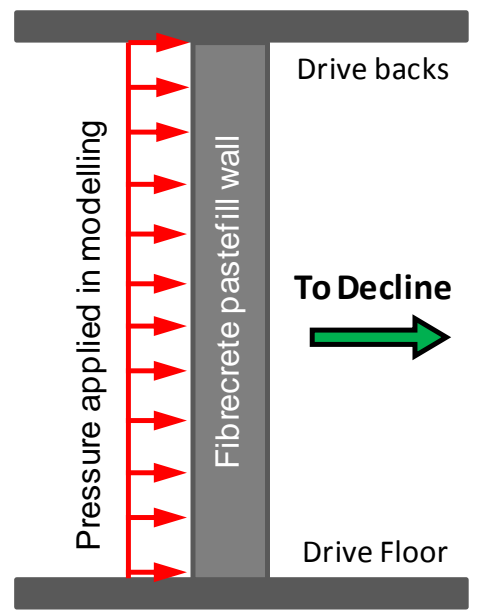

(a)

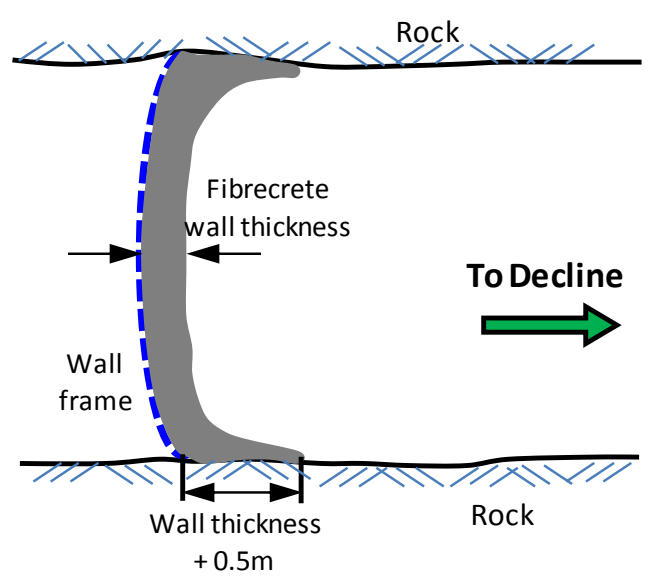

(b)

Figure 4 (a) vertical section sketching pressure applied on the wall in numerical modelling; and (b) horizontal section of fibrecrete wall spraying requirement at Cannington Mine

For the different fill wall widths that were modelled, the results show that the fill wall height has minimal impact on the ultimate fill wall capacity between 5-7 m, as shown by the similar curves in Figure 5. For simplicity of the relationship between ultimate fill wall capacity and wall thickness, the lowest fill wall capacity for each width (curve) and thickness (point on curve) has been shown in Figure 6 for both arched (a) and flat (b) Kit walls. 


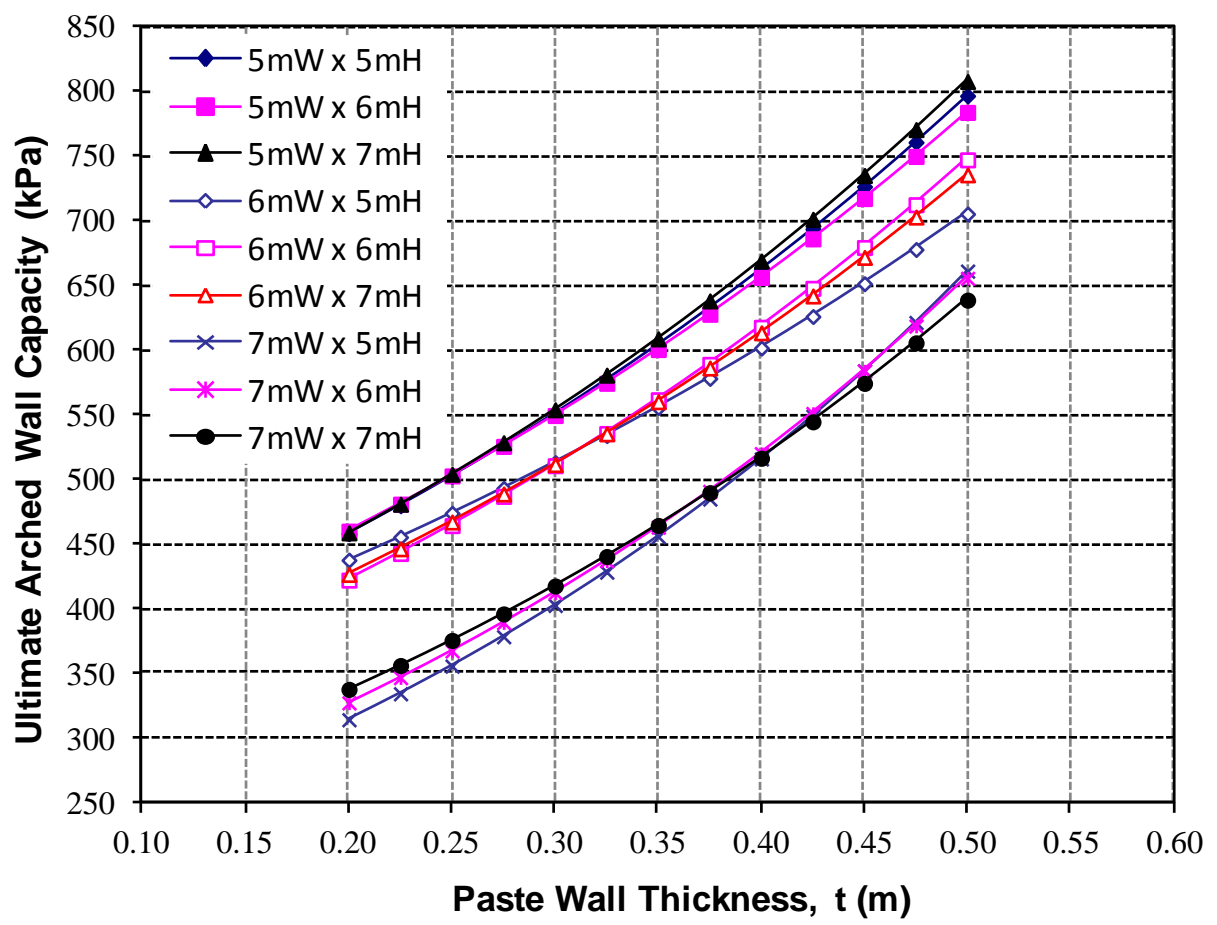

Figure 5 Modelling provided ultimate capacities of arched Kit walls with three widths and three heights

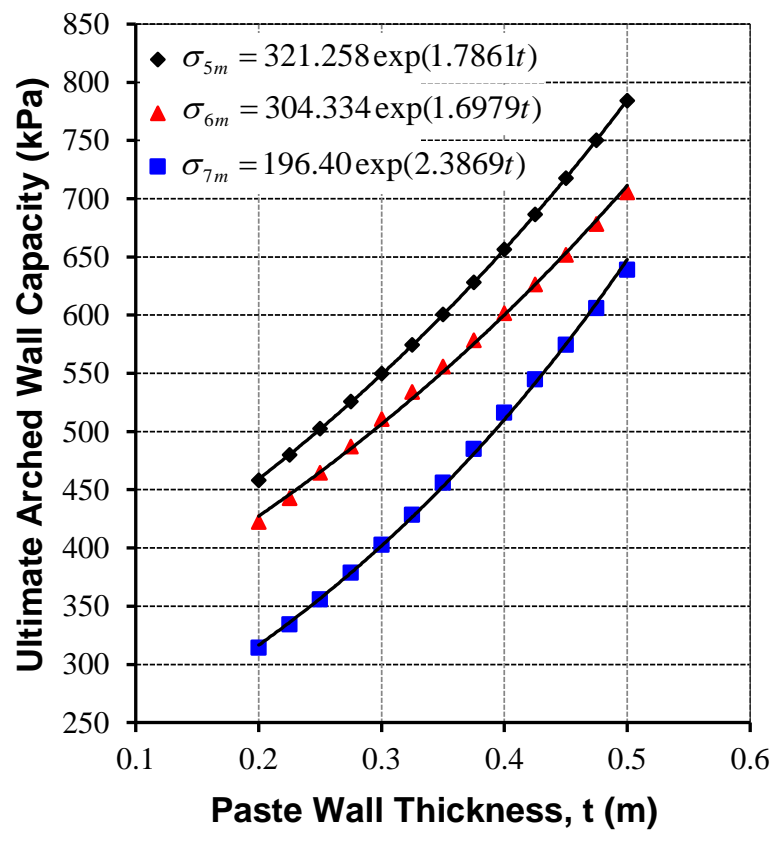

(a)

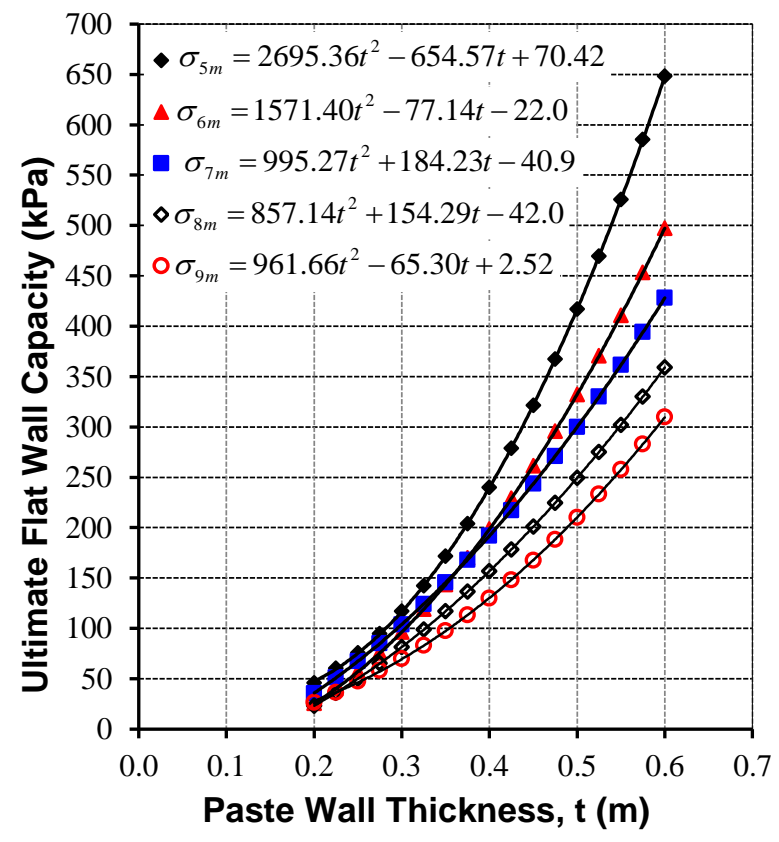

(b)

Figure 6 Relationships of the ultimate capacities with paste wall thickness for a given wall width for (a) the arched walls; and (b) the flat walls

The relationship between the ultimate wall capacity and wall width can be established using the equations presented in Figure 6 . As the width of a fill wall is determined by the width of the drive where the fill wall is installed, a relationship between the controllable input, wall thickness, and ultimate capacity is needed for a range of fill wall thicknesses. As the walls are constructed of sprayed fibrecrete, which cannot be constructed to millimetre accuracy, their thicknesses were chosen in $50 \mathrm{~mm}$ increments from a minimum of 
$200 \mathrm{~mm}$ to maximum $400 \mathrm{~mm}$. Figure 7 shows the relationships of the ultimate capacity with width for arched Kit walls of a given thickness.

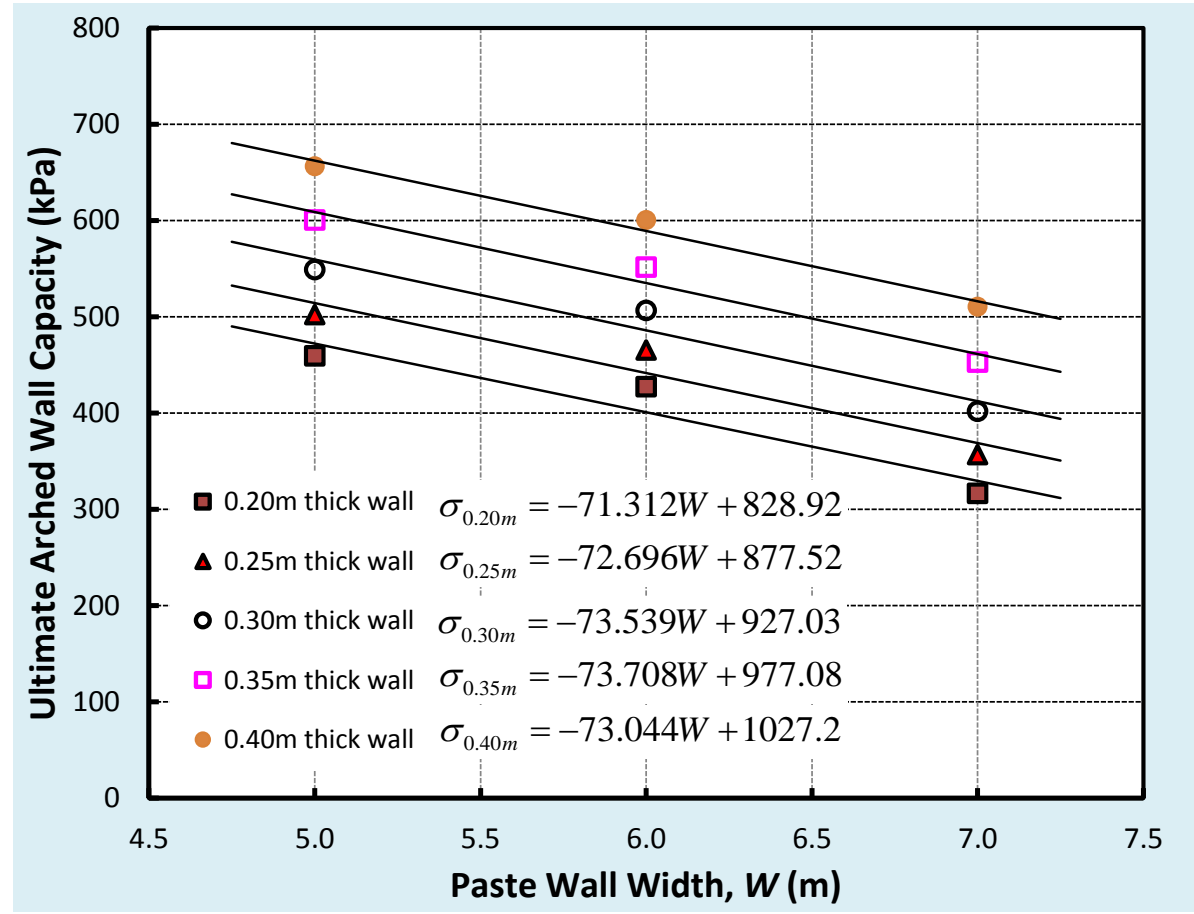

\section{Figure 7 Relationships of the arched wall ultimate capacities with width for a given thickness}

\section{$4 \quad$ Paste fill wall pressure monitoring}

Numerous instruments are available for measuring the pressure that paste fill imposes on fill walls during filling (Yumlu \& Guresci 2007; Grabinsky \& Bawden 2007; Bawden 2010, Hughes et al. 2010). Geokon 4850-1 water filled stress cells of $700 \mathrm{kPa}$ capacity were used for this project, in conjunction with a single channel Vibration Wire Data Logger attached with $110 \mathrm{~m}$ of cable. The length of cable was to mitigate the risk of exposing personnel to potential wall failure during the continuous fill trial stage.

Calibration of a stress cell was conducted prior to any of them being used underground. The measured pressure was compared to the actual applied pressure from liquid paste weights. In general, the measured pressure was greater than the calculated actual pressure; and the difference increased with increased actual pressure. The over reporting of pressure was acceptable as it added no additional risk to the data collection process.

To mitigate the risk of fill wall failure during the continuous fill trials, all the fill walls were sprayed to a minimum thickness of $400 \mathrm{~mm}$ and initial trials were conducted to paste fill runs with a low vertical rate of rise (up to $1.15 \mathrm{~m} / \mathrm{hr}$ ). The stress cells were installed into the fill wall frame prior to spraying the frame with fibrecrete, to ensure the paste fill acted directly on the stress cell. The stress cells were cast in dental plaster and the data cable was run through conduit to reduce the risk of damage during spraying, see Figure 8. 


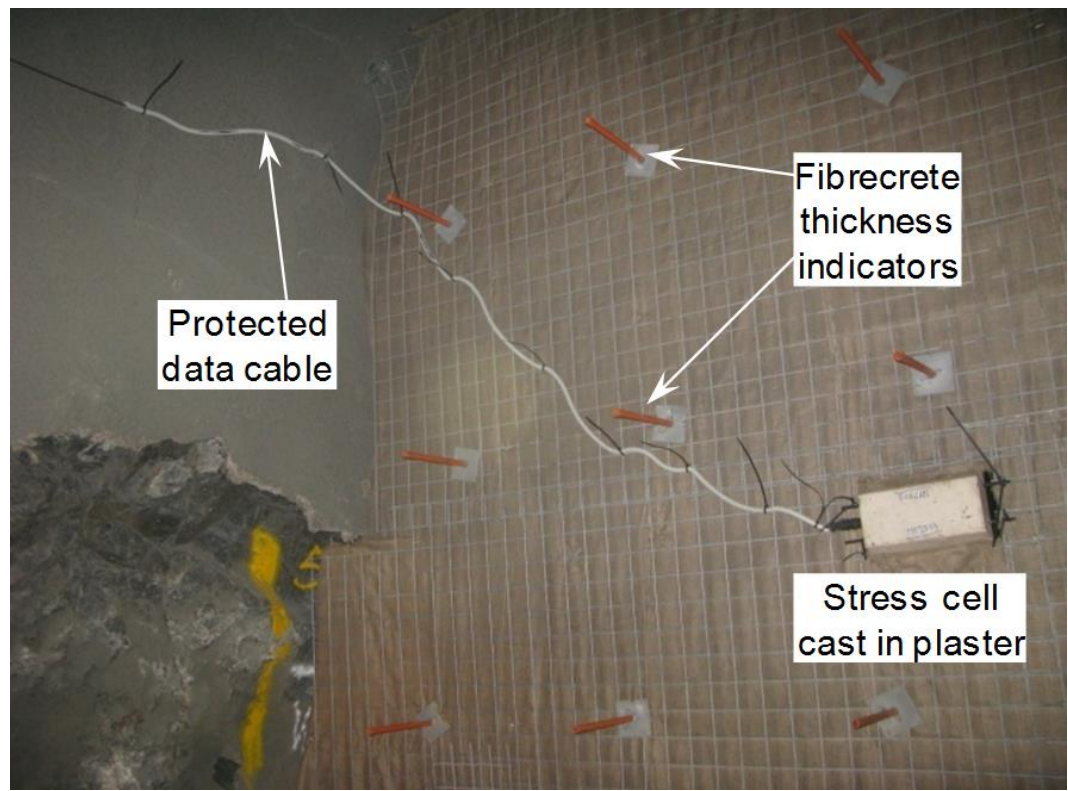

\section{Figure 8 Plaster cast stress cell installed on a flat Kit wall frame ready for fibrecreting}

Wall width, paste filling details and the pressures measured for a total of nine walls are presented in Table 1. Table 1 and Figure 9 show that lower the cement content in the paste fill and the higher the vertical rate of rise $\left(V_{R}\right)$, then the higher the pressure applied on the wall. The lowest cement addition for paste fill at Cannington is $2.7 \%$ by weight.

From the data gathered for paste fill cement content between 2.7 and $3.1 \%$ a line of best fit function was interpolated, shown in Figure 9. No monitoring data was gathered between 1.15 and $2.84 \mathrm{~m} / \mathrm{hr}\left(V_{R}\right)$. There was enough confidence that additional data would not significantly change the general trend established from the existing data that it could be used for routine continuous filling application.

Table 1 Monitored pressure and related wall and paste fill information

\begin{tabular}{cccccc}
\hline $\begin{array}{c}\text { Wall } \\
\text { no. }\end{array}$ & $\begin{array}{c}\text { Wall width } \\
(\mathbf{m})\end{array}$ & Wall type & $\begin{array}{c}\text { Cement in } \\
\text { paste fill }(\%)\end{array}$ & $\begin{array}{c}\text { Vertical rate of } \\
\text { rise }(\mathbf{m} / \mathbf{h r})\end{array}$ & $\begin{array}{c}\text { Measured peak } \\
\text { pressure (kPa) }\end{array}$ \\
\hline 1 & 5.3 & Arched & 4.3 & 0.22 & 5 \\
2 & 5.5 & Arched & 3.7 & 0.23 & 4 \\
3 & 5.2 & Arched & 3 & 1.15 & 24 \\
4 & 5.4 & Flat & 3.1 & 0.55 & 26 \\
5 & 5.3 & Flat & 4 & 0.27 & 5 \\
6 & 7 & Flat & 3.8 & 1.10 & 19 \\
7 & 5.3 & Arched & 2.7 & 2.84 & 130 \\
8 & 5.7 & Arched & 2.7 & 2.95 & 142 \\
9 & 5.5 & Arched & 2.7 & 0.50 & 16 \\
\hline
\end{tabular}




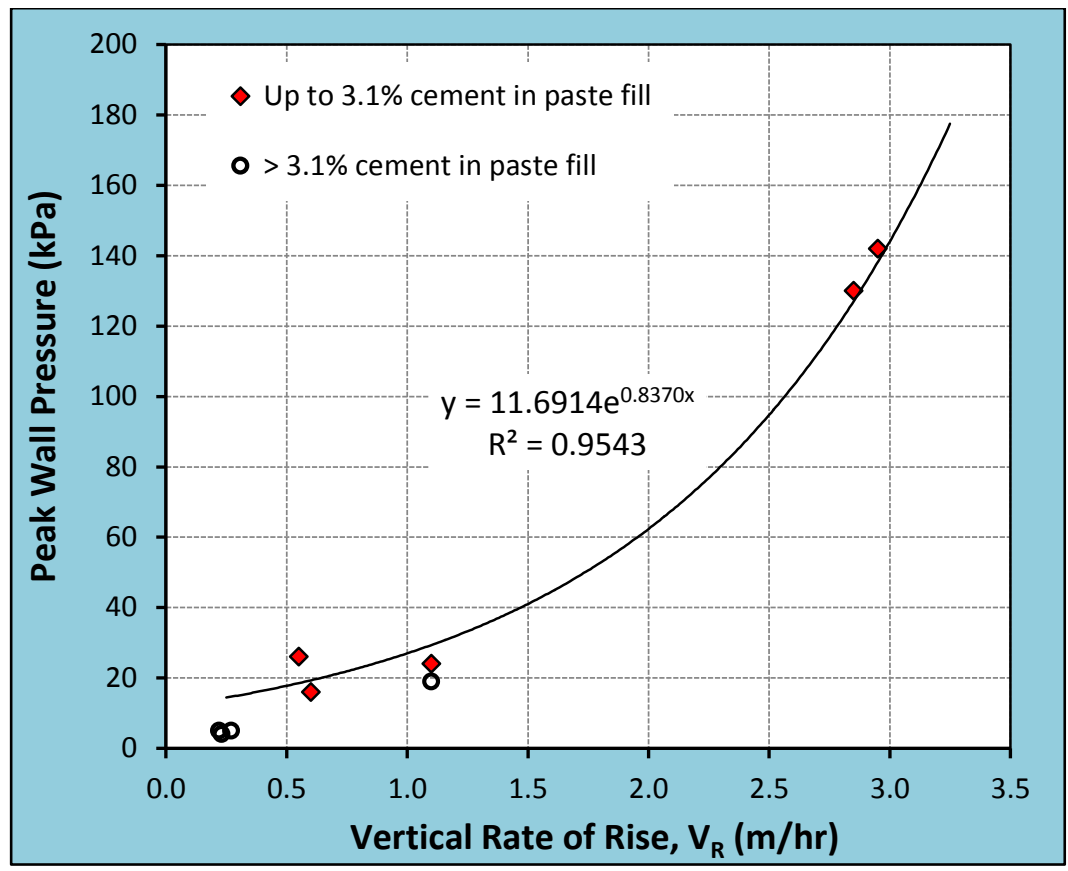

Figure 9 Peak wall pressure versus vertical rate of rise for all monitored walls

Figures 10 and 11 show the surveyed shape of paste filled stopes and the monitored wall pressure, pore pressure and temperature changes over time, for walls No. 6 and 7 respectively. Figure 12 shows the monitoring data for walls No. 3 and 8. Observations from the data gathered are:

1. The fill wall pressure and pore pressure were the same in the first two hours after paste fill placement.

2. The fill wall pressure was higher than the pore pressure once cement hydration has started in the paste fill.

3. The peak pressure was reached four hours after the paste fill placement, regardless of the cement content.

4. The temperature decreased when the paste fill first reached the stress cell but increased over time due to cement hydration.

5. Both wall and pore pressures were always lower than the peak values even though the stope voids were filled continuously from draw point level to crown level, except the wall No. 7 which was only continuously filled from 425 to $400 \mathrm{mLv}$ (Figure 12).

6. The monitored peak pressure applied on the wall was considerably less than the calculated hydrostatic pressure of the paste. This would be caused by the fast cement hydration and the distance the fill wall location was from the stope brow, on average 5-7 m. 
$400 \mathrm{mLv}$

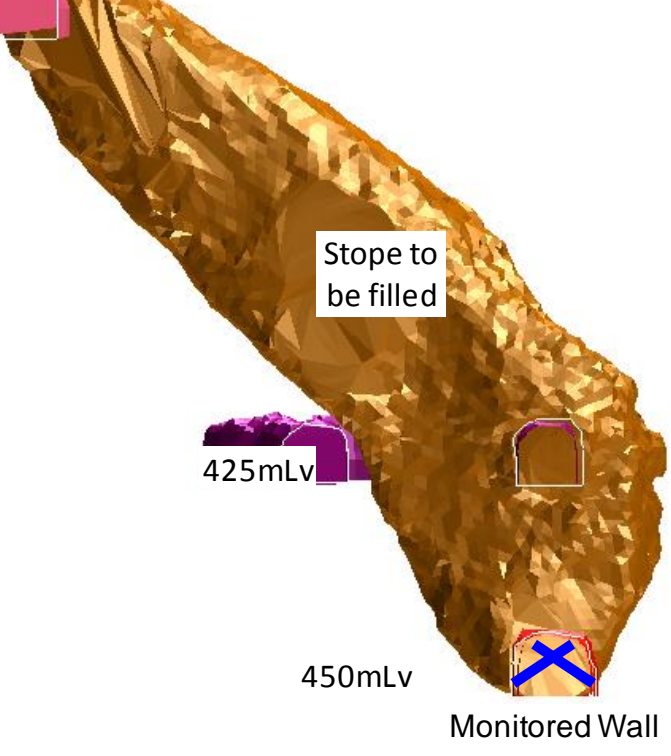

(a)

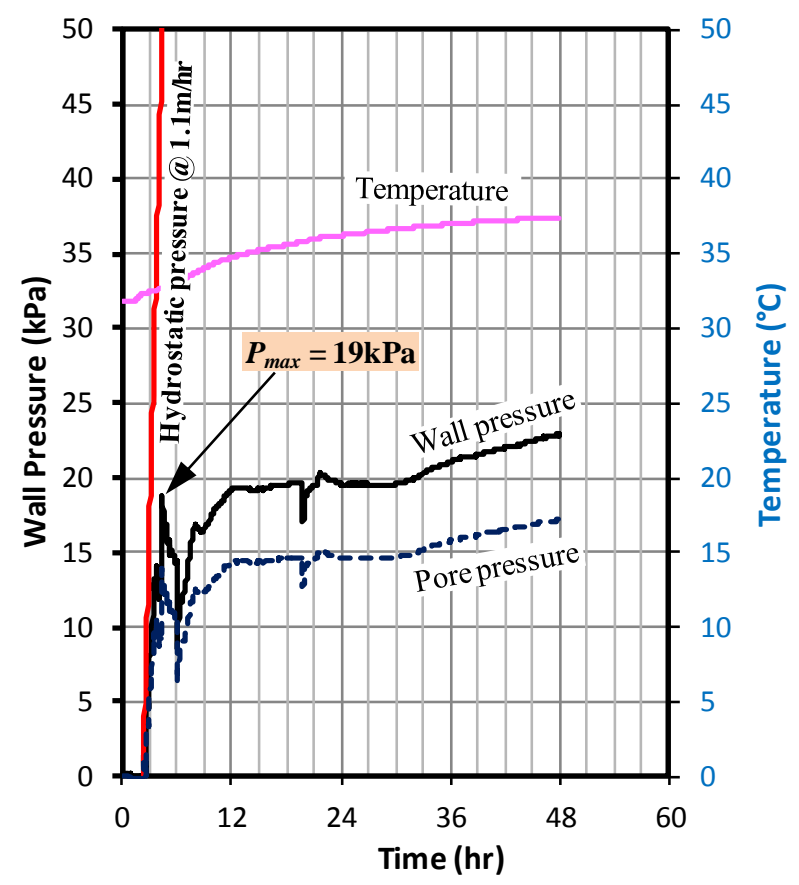

(b)

Figure 10 Stope voids and pressure monitored wall location (a); and the monitoring data (b); for wall No. 6

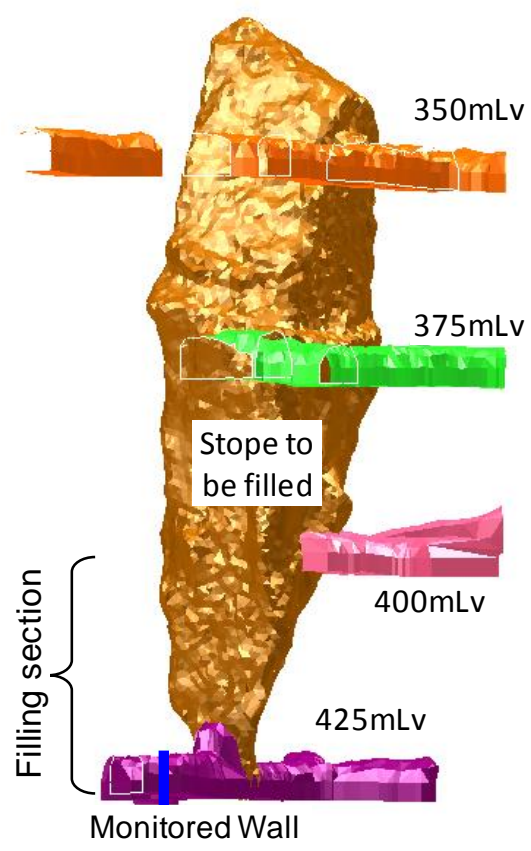

(a)

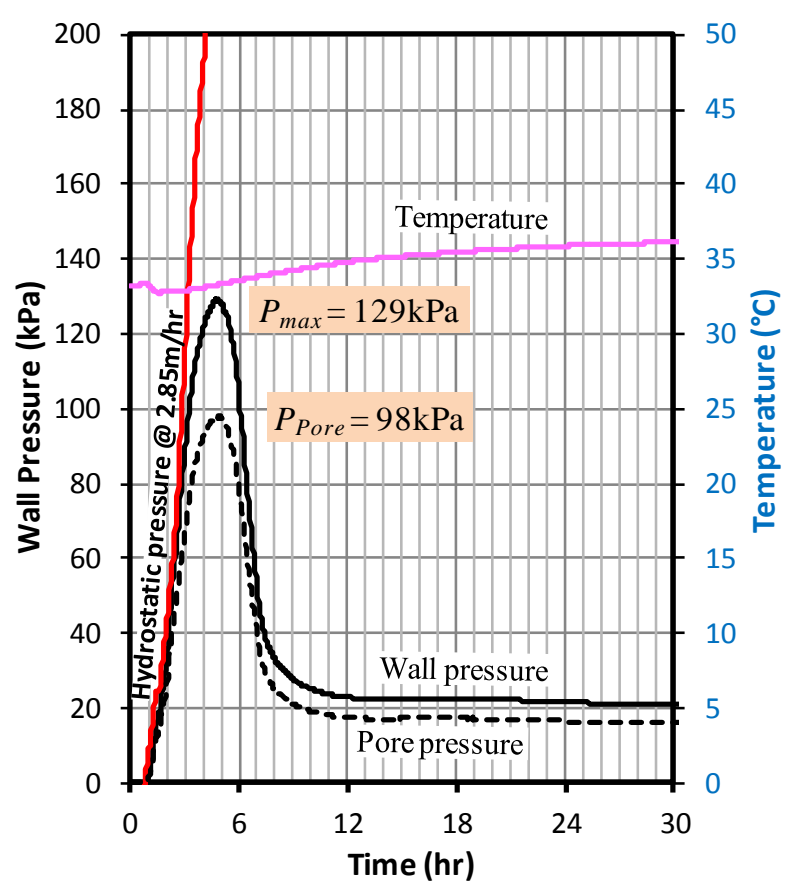

(b)

Figure 11 Stope voids and pressure monitored wall location (a); and the monitoring data (b); for wall No. 7 


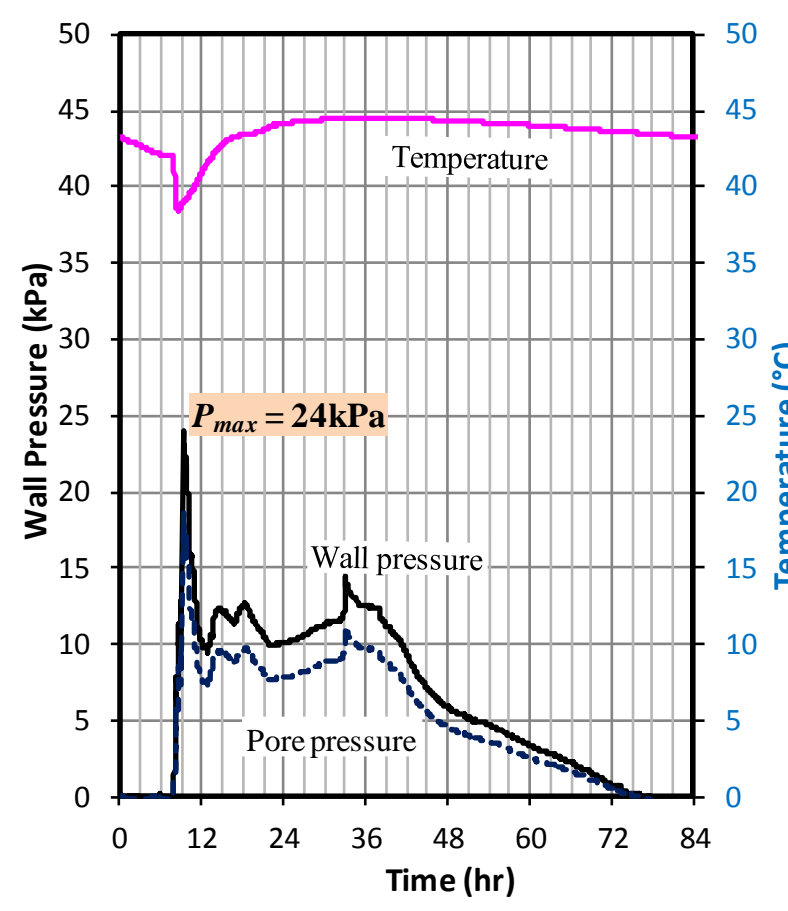

(a)

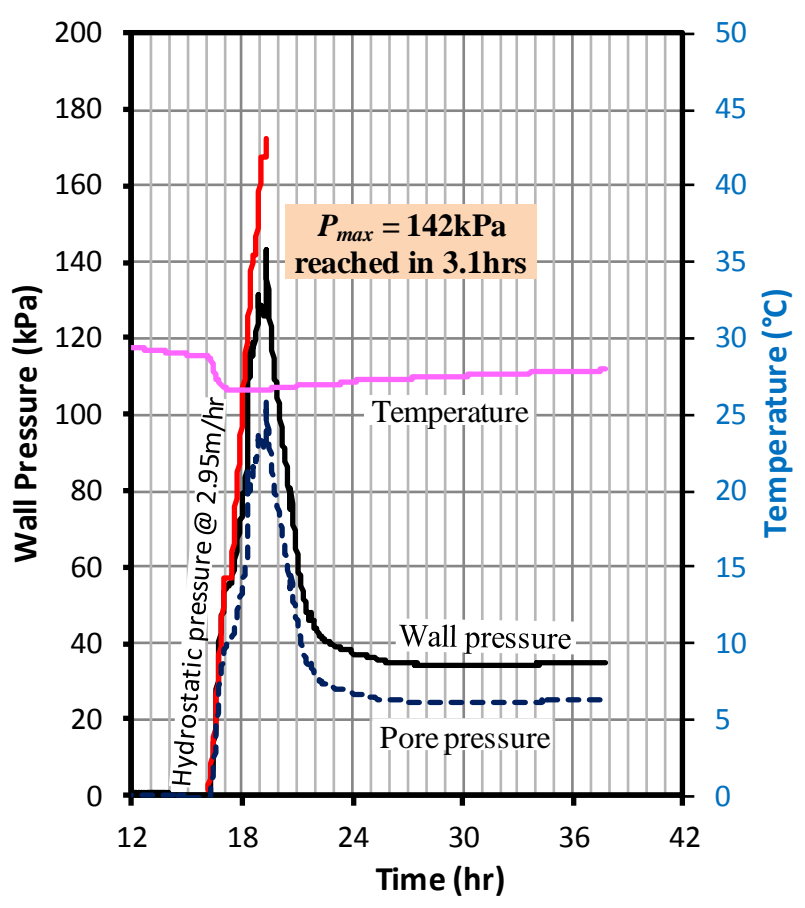

(b)

Figure 12 Wall pressures and temperature versus time curves for walls No. 3 (a); and No. 8 (b)

\section{$5 \quad$ Transition from discontinuous to continuous filling strategy}

The results of the continuous fill trials supported the hypothesis that continuously paste filling past a fill wall could be conducted safely with certain controls in place.

\subsection{Factor of Safety}

The relationship between measured peak wall pressure $P_{\text {Measured }}$ and vertical rate of rise $\left(V_{R}\right)$ is represented in Equation (1). This equation is valid for all cement contents used at Cannington mine for paste fill from $2.7-6 \%$.

$$
P_{\text {Measured }}=11.6914 \exp \left(0.8370 V_{R}\right)
$$

Due to the potential variability of paste fill quality and paste producing rates in the paste plant, either above or below design, a Factor of Safety (FoS) of 2 was applied to get the design wall pressure $\left(P_{\text {Design }}\right)$ from Equation (1), i.e.

$$
\begin{gathered}
{F o S_{1}}=2 \\
P_{\text {Design }}=F o S_{1} \times P_{\text {Measured }}=23.3828 \exp \left(0.8370 V_{R}\right)
\end{gathered}
$$

Figure 13 compares the design pressure $\left(P_{\text {Design }}\right)$ and measured peak pressure $\left(P_{\text {Measured }}\right)$. 


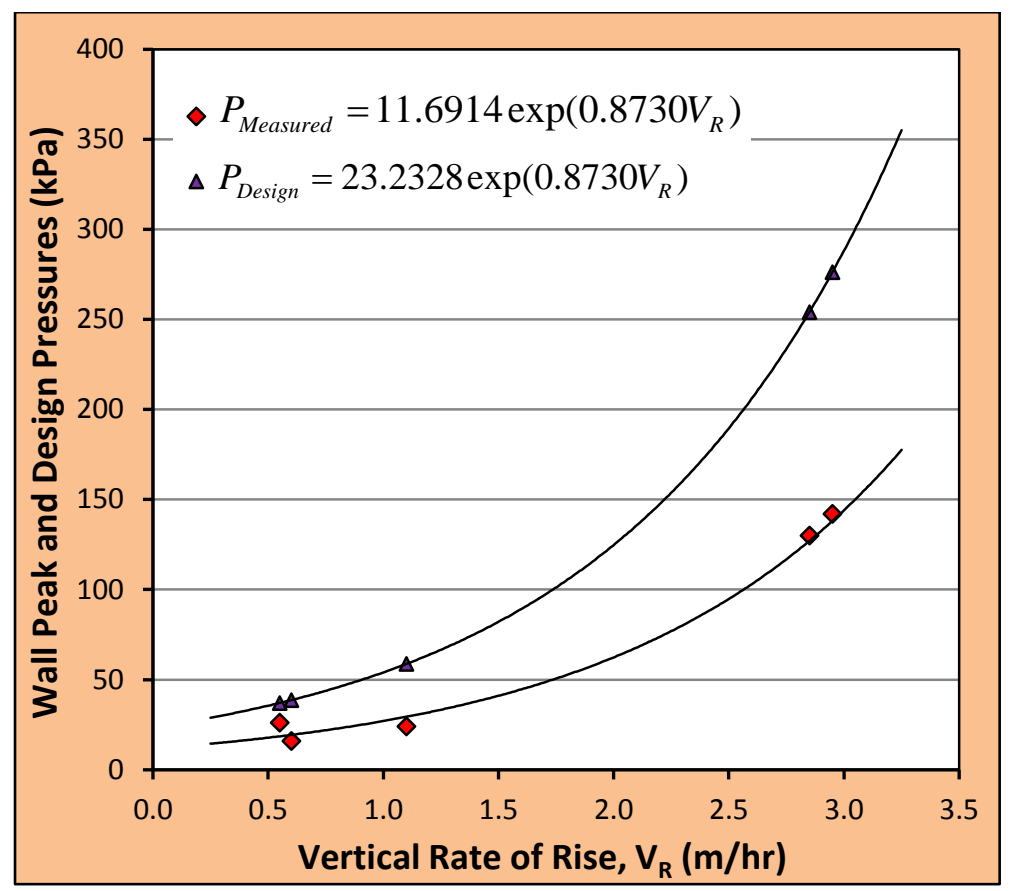

Figure 13 Paste fill wall peak and design pressures versus the vertical rate of rise

A Factor of Safety was also applied to the fill wall capacity. Revell et al. (2009) recommended that a Factor of Safety of 1.8 be applied to the fill wall capacity due to the potential variability of fibrecrete quality and the potential for fill walls not to be sprayed to design thickness.

$$
\mathrm{FoS}_{2}=1.8
$$

These two factors of safety represent two independent parameters in the continuous paste fill design, therefore, the overall factor of safety for continuously paste filling past a fill wall becomes:

$$
F o S=F o S_{1}+F_{o S}=3.8
$$

\subsection{Fill wall design}

To ensure the continuous filling strategy was implemented safely and the design parameters followed a design tool was established. The fill wall capacity is a function of fill wall width, type and thickness, the width of the wall is determined by the drive dimensions that it is installed in. The thickness and type can be changed to increase fill wall capacity. The required fill wall capacity is based on the pressure imposed on it by the uncured paste fill. From above this is a function of the vertical rate of rise of the paste fill in the stope. The vertical rate of rise of paste fill is determined by the dimensions of the void being filled and the paste plant capacity. The dimensions of the void being filled can't be changed and it is optimal to run the paste plant at its capacity.

Fill wall thickness and type are the controllable variables. A design template was created to return wall thickness and type, based on the inputs of width, height, and vertical rate of rise. If the fill wall dimensions are outside the limits of Kit walls, then a Jumbo wall is installed and the stop and cure process is followed, all jumbo walls are sprayed to a minimum of $400 \mathrm{~mm}$ thick. If the vertical rate of rise is too high and returns a thickness greater than maximum $400 \mathrm{~mm}$ then the paste plant can be restricted to a slower rate to reduce the vertical rate of rise past the fill wall in question. 


\begin{tabular}{|c|c|c|c|c|c|c|c|c|c|c|}
\hline \multicolumn{11}{|c|}{ Continuous Pastefill and Fibrecrete Wall Thickness Design Template } \\
\hline \multicolumn{11}{|c|}{ Enter details in the boxes shaded Yellow } \\
\hline & \multicolumn{4}{|c|}{ Stope To Be Filled } & \multicolumn{3}{|c|}{$X X X . X X H L$} & \multirow[b]{2}{*}{ Wall 8} & \multirow[b]{2}{*}{ Wall 9} & \multirow[b]{2}{*}{ Wall 10} \\
\hline Input Section & Wall 1 & Wall 2 & Wall 3 & Wall 4 & Wall 5 & Wall 6 & Wall 7 & & & \\
\hline Level (mLv): & 520 & 500 & 500 & 475 & 450 & & & & & \\
\hline Drive Name: & $54 \mathrm{XC}$ & $54 \mathrm{XC}$ & TC63DS & $54 \mathrm{XC}$ & $54 \mathrm{XC}$ & & & & & \\
\hline Drive Width $(\mathrm{m})$ : & 5.3 & 7.6 & 5.7 & 7.1 & 7.3 & & & & & \\
\hline Drive Height (m): & 5.4 & 5.3 & 5.5 & 5.3 & 6.0 & & & & & \\
\hline Design Vertical Rise Rate $(\mathrm{m} / \mathrm{hr})$ : & 1.50 & 0.60 & 3.20 & 1.15 & 1.80 & & & & & \\
\hline Results & Wall 1 & Wall 2 & Wall 3 & Wall 4 & Wall 5 & Wall 6 & Wall 7 & Wall 8 & Wall 9 & Wall 10 \\
\hline Arched Wall Thickness (mm): & 200 & N/A & 400 & 200 & 200 & & & & & \\
\hline Fibrecrete for Arched Kit Walls $\left(\mathrm{m}^{3}\right)$ : & 8.3 & N/A & 18.2 & 10.9 & 12.7 & & & & & \\
\hline Flat Wall Thickness $(\mathrm{mm}):$ & 400 & 350 & \begin{tabular}{|c|c} 
Not \\
Recomd
\end{tabular} & 400 & $\begin{array}{c}\text { Reduce } \\
\text { Rate }\end{array}$ & & & & & \\
\hline Fibrecrete for Flat Kit Walls $\left(\mathrm{m}^{3}\right)$ : & 16.6 & 20.4 & N/A & 21.8 & N/A & & & & & \\
\hline
\end{tabular}
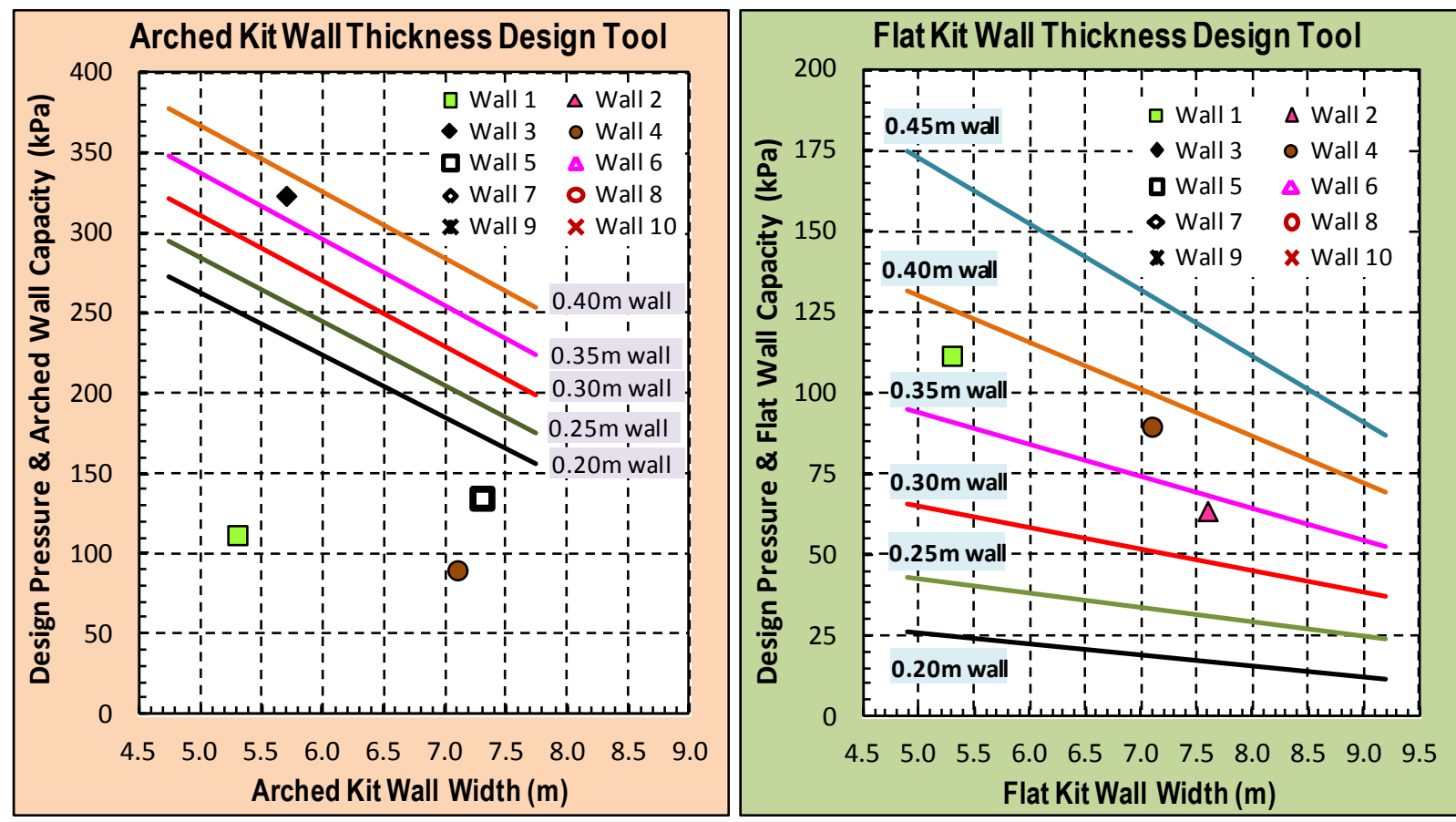
Figure $14 \begin{gathered}\text { Continuous paste fill design template and plots showing the design } \\ \text { pressure related to the reduced wall capacity by } \mathrm{FoS}_{2}=1.8\end{gathered}$

\subsection{Implementation of the continuous filling strategy in operations}

In order to implement the continuous paste filling process, all the potential risks needed to be assessed and controlled. The variables in fill wall capacity are the fill wall thickness and type. The fill wall thickness and type are controls to mitigate fill wall failure while continuously filling, and sign-off checklists were created to ensure that the correct design fill wall thickness and type are installed at each fill wall location.

All fill walls for continuous filling are required to cure for a minimum of 48 hours prior to commencing paste filling past a fill wall, as this was the assumption for the fill wall capacity modelling.

The continuous filling process at Cannington mine has been applied without incident since project completion in early 2012. The benefits experienced from the continuous paste filling are:

- Reduced fibrecrete consumption in fill wall construction by $30 \%$. The reduced quantity of fibrecrete per annum is equivalent to one month consumption of development ground support. 
- Time saved by reducing the time taken to spray fill walls is used for development ground support, and hence increases development productivity.

- Increased paste plant utilisation, by reducing the down time experienced due to underground factors by $15-20 \%$, achieved by a significant reduction in stops and line changes after each paste fill run.

- Increased underground paste crew productivity and reduced safety risk by reducing line changes.

- Improved fill mass integrity, by reducing stops and line changes, every stop and start of paste filling requires the reticulation system be flushed with water, which results in cold joints and thus paste fill strength reduction.

\section{Conclusions and future improvements}

Transition from discontinuous to continuous paste filling at Cannington mine was successfully implemented in early 2012. Continuous filling has been in operation without incident and has shown proven productivity improvements at Cannington mine.

The project had rigorous data collection and analysis phases. The outcomes proved with confidence that the previous controls, stop and cure processes, to mitigate the risk of fill wall failure during paste filling were conservative. The discontinuous paste filling processes could be changed, posing no additional risk, to realise productivity improvements and operational cost reductions.

The continued success of continuous filling can be attributed to creating a robust fill wall design tool and check process, which ensures that all controls recommended from the project are followed systematically, consistently and to the required standard.

A conservative Factor of Safety (3.8) is used in the current continuous filling design. This is required in the initial stages of the continuous filling process implementation. The overall Factor of Safety may be reduced after more pressure monitoring data is obtained, associated with actual pulp density, cement content and the vertical rate of rise of paste fill.

Another possible improvement is to analyse the capacity of Jumbo walls and apply a similar design process to the Kit fill walls, to either move away from $400 \mathrm{~mm}$ thick Jumbo walls for discontinuous filling process or allow continuous filling past Jumbo walls.

\section{Acknowledgement}

The authors appreciate BHP Billiton and Cannington Mine for their support and permission to publish this paper. The authors are also grateful to general manager Troy Wilson and former manager mining Ed Cooney for their encouragement and support throughout the project establishment to implementation of the continuous filling strategy at Cannington mine. During this project, underground services crews provided help to install the stress cells; geotechnical engineer Andrew Clarkson and paste engineer Shaun Ritchie helped in the fill wall pressure monitoring.

\section{References}

Bawden, WF 2010, 'Field instrumentation of paste backfill', Keynote speech presentation for the Eastern Australia Ground Control Group workshop, Brisbane, May 2010.

Bernard, S 2006, Early age fibre reinforced shotcrete lining capacity for BHP Billiton - Cannington, a consulting report from Technology in Structural Engineering P/L, Penrith, no. 163.

Bloss, M \& Revell, MB 2000, 'Cannington paste fill system - achieving demand capacity', in G Chitombo (ed.), Proceedings of MassMin 2000, Australasian Institute of Mining and Metallurgy, Melbourne, pp. 713-20.

Grabinsky, MW \& Bawden, WF 2007, 'In situ measurements for geomechanical design of cemented paste backfill systems', in FP Hassani \& JF Archibald (eds), Proceedings of the 9th International Symposium on Mining with Backfill, Canadian Institute of Mining, Metallurgy and Petroleum, Westmount, paper \#2456, on CD-ROM. 
Helinski, M, Fahey, M \& Fourie AB 2007, 'An effective stress approach to modelling mine backfill', in FP Hassani \& JF Archibald (eds), Proceedings of the 9th International Symposium on Mining with Backfill, Canadian Institute of Mining, Metallurgy and Petroleum, Westmount, paper \#2479, CD-ROM.

Hughes, PB, Pakalnis, R, Hitch \& Corey, G 2010, 'Composite paste barricade performance at Goldcorp Inc. Redlake Mine, Ontario, Canada', International Journal of Mining, Reclamation and Environment, vol. 24, pp. 138-50.

Li, J, Todd, JK \& Campbell, A 2011, 'Ground support design and application for developing in paste fill at BHP Billiton - Cannington Mine', Proceedings of the $11^{\text {th }}$ AusIMM Underground Operators' Conference, The Australasian Institute of Mining and Metallurgy, Canberra, pp. 201-6.

Revell, MB, Helinski, M, Wines, D \& Sainsbury, DP 2009, 'BHPB Cannington sprayed fibrecrete bulkhead design', technical consulting report to Cannington mine from Revell Resources Pty Ltd and Itasca Australia Pty Ltd.

Sainsbury, DP \& Revell, MB 2007, 'Advancing paste fill bulkhead design using numerical modelling', CIM Bulletin, vol. 100, no. 1103, paper \#25.

Thompson, B, Grabinsky, MW, Bawden, WF \& Counter, DB 2009, 'In situ measurement of cemented paste backfill in long-hole stopes', in M Diederichs \& G Grasselli (eds), Proceedings of the 3rd CANUS Rock Mechanics Symposium (ROCKENG09), Toronto, paper \#4061.

Yumlu, M \& Guresci, M 2007, Paste backfill bulkhead failures and pressure monitoring at Cayeli Mine, CIM Bulletin, vol. 100, no. 1103 , paper \#22. 